\title{
Claims Management and Financial Performance of Insurance Companies in Rwanda: A Case of SONARWA General Insurance Company Ltd.
}

\author{
Alphonse Ntwali*, Alice Kituyi, Athanas Osiemo Kengere \\ School of Business and Economics, Mount Kenya University, Kigali, Rwanda \\ Email: *alphonsentwali002@gmail.com
}

How to cite this paper: Ntwali, A., Kituyi, A., \& Kengere, A. O. (2020). Claims Management and Financial Performance of Insurance Companies in Rwanda: A Case of SONARWA General Insurance Company Ltd. Journal of Financial Risk Management, 9, 190-210.

https://doi.org/10.4236/jfrm.2020.93011

Received: July 2, 2020

Accepted: August 16, 2020

Published: August 19, 2020

Copyright $\odot 2020$ by author(s) and Scientific Research Publishing Inc. This work is licensed under the Creative Commons Attribution International License (CC BY 4.0).

http://creativecommons.org/licenses/by/4.0/

(c) (i) Open Access

\begin{abstract}
Worldwide, insurance companies play a vital role in contributing to the efficient resources allocation through risk management in most sectors of the economy. Insurance has existed since civilizations initially presenting itself in the form of mutual help. One of the fundamental services offered by the insurance company is to provide its customers with claims settlement. The general objective of this study was to assess the effects of claims management on financial performance of insurance companies. The study used a case study research design whereby descriptive approaches were applied to collect quantitative and qualitative data using questionnaire and interview guide. The researcher targeted 93 permanent employees, 10 registered agents, 13 contracted brokers, and 205 claimants in Kigali City. Findings on claims management processes in SONARWA General Insurance which are claims planning, claims control, claims monitoring and evaluation show that they are frequently undertaken as it is indicated by the weighted means ranging between $1.00 \leq$ mean score $\leq 1.50$. The financial ratios indicate that there is a constant stagnation of financial performance as indicated by $3.6 \%$ of ROI in 2014 and the same percentage in 2018. Although there has been a sharp increase in 2016 followed by a sharp decrease in 2017 on ROE and ROA, the graph indicates that these have been approaching stagnation over other years. However, the correlation is not statistically significant. It was observed that claims planning and claims $\mathrm{M} \& \mathrm{E}$ has a significant positive correlation with ROI indicated by a Pearson Correlation value of $\left(0.481^{\star *}\right.$ and $\rho$-value of $0.000 ; 0.329^{\star}$ and a $\rho$-value of $\left.0.015: \rho \leq 0.05\right)$. Finally, the study established that there is a positive correlation between claims planning, claims control and claims $\mathrm{M} \& \mathrm{E}$ on ROE. Moreover, the correlation between claims $\mathrm{M} \& \mathrm{E}$ and ROE is statistically significant as indicated by Pearson correlation value of $0.276^{*}$ and $\rho$-value of 0.043: $\rho \leq 0.05$ ). The researcher recommends that proper claims planning needs to be put in place which promptly handles
\end{abstract}


claims management in order to avoid having a lot of outstanding claims. The study also recommends that the company needs to invest more on empowering its clients especially by leveraging the advanced technology in order to reach out to their clients on real time in order to avoid late notification and improve customer experience.

\section{Keywords}

Claims, Management, Financial Performance, Insurance, Company

\section{Introduction}

\subsection{Background of the Study}

Worldwide, insurance companies play a vital role in contributing to the efficient resources allocation through risk management in almost all sectors of the economy. Insurance has existed since civilizations initially presenting itself in the form of mutual help. One of the fundamental services offered by the insurance company is to provide its customers with claim settlement. Claims settlement process therefore acts as an important part of the insurance services. Insurance companies therefore ought to find a way of management privileges settlement in a prompt, proactive and optimistic method (Ashturkar, 2014).

African Insurance Organizations (AIO), which controls about $\$ 69$ billion insurance markets, released its first Africa Insurance Barometer aimed at improving the transparency. The report pointed out that the main drivers behind the poor results of insurance companies in Africa are attributed to poor claims management practice. For instance, motor insurance has been rated the most frequently least profitable line of business due to frequent competitiveness of motor insurance. This has led to insurance companies registering low levels of profitability and high claims inflation (Kusimo, 2016).

Wairimu (2010) conducted a study to identify the key challenges that public insurance companies faced in Kenya's claims management and found that weak sales records, high fraud, and reporting delays and high workload of employees were key factors contributing to delaying payment.

In Rwanda, the insurance companies are paying claims yet they still receive complaints from its clients. BNR (2018) argued that an increase in car accidents in motor vehicles in Rwanda has been driving general profit margins for privacy creation. This has been pointed out to poor subcontract risk assessment, price protection and high report feces.

The improvement of their profits further, private insurers need to appropriately set prices for their products, diversify their insurance products and put in place controls to reduce fraud. Hence, BNR has proposed to support these interventions, in 2016 by issuing a directive on conducting insurance business that required, among other things, insurers to put in place underwriting and pricing policies forbidding Insurers to sell insurance on credit. 


\subsection{Statement of the Problem}

Globally, clients expect the insurance company to quickly settle claims and to their satisfaction. Due to the high level of customer satisfaction required, a company with a competitive advantage always works towards reducing the time it takes to settle insurance claims which is one way to reduce the number of customer complaints and improve customer service. There are cases in which an insurance company loses money due to poor assessment of claims and poor reserve management strategies (Vanguard, 2017).

The claims ratio in insurance sector has been fluctuating between $62 \%$ and $78 \%$ during 2014-2018 but was decreased to $62 \%$ in 2018. Also, operating expenses hit the bottom line of the insurance companies and the expense ratios have been fluctuating between $41 \%$ and 50\% with $41 \%$ registered in 2018 the least percentage. These two financial factors are reflected in the overall financial performance of the insurance company. Regarded through financial performance indicators, the Rwandan insurance industry has not performed well compared to the minimum acceptable ROE (16\%) and ROA (4\%). The statistics published by BNR (2018) show that ROE fluctuated between $-24 \%$ and $10 \%$ and the ROA ranged between $-7 \%$ to $3 \%$ during the period under review. Though there has been continuous improvement of the above two indicators over the years, 2018 has registered an ROE of $10 \%$ and ROA of 3\%; which are still under the above minimum required by the regulator (BNR, 2018).

Besides the above overall situation in the industry, there are particular cases noticed on SONARWA General Insurance Company as a pioneer of insurance in Rwanda. The company has been facing cases of unpaid claims advanced by clients and multiple law suits. Missing policy documents in the system and some service providers turning away Sonarwa General due to unsettled claims (Gahigi, 2017). Therefore, there is a need to investigate on the impact of claims management towards financial performance of SONARWA General Insurance.

\subsection{Research Objectives}

\subsubsection{General Objective}

The general purpose of this research is to assess the effects of claims management on financial performance of insurance companies.

\subsubsection{Specific Objectives}

1) To examine claims management processes in SONARWA General Insurance.

2) To assess the level of financial performance indicators in SONARWA General Insurance.

3) To establish the relationship between claims management and financial performance in SONARWA General Insurance.

\subsection{Research Questions}

1) What are the claims management processes used in SONARWA General Insurance? 
2) How is the level of financial performance indicators in SONARWA General Insurance?

3) What is the relationship between claims management processes and financial performance in SONARWA General Insurance?

\subsection{Significance of the Study}

The results from this research are vital to insurance companies to develop and establish different insurance schemes likely to contribute to the management of risks. The findings of this study reveal that different insurance products and use of appropriate techniques and methods of claims management can help to increase the monetary performance of insurance business.

This research will improve the skills and knowledge of the researcher related to insurance matters in Rwanda and internationally. This research will also help the insured to know and to understand opportunities and advantages which are reserved to them through various insurance schemes which are developed and established by insurance companies and more particularly SONARWA General Insurance Company so as to strengthen the interaction between insurance companies and their insured. This research will serve a scientific interest to enrich the documentation resources of Mount Kenya University's library.

\section{Literature Review}

\subsection{Overview of Insurance Sector in Rwanda}

Before 1975 there were no complete insurance companies present in Rwanda. Nevertheless, some external brokerage companies were operating in Rwanda on behalf of their insurance firms based in Europe. The recognized one among these was Charles Le Jeune. These companies had ability and were authorized to carry out underwriting and claims administration tasks.

The Government of Rwanda enacted two laws related to insurance in 1975; one law regulating operations of insurance (June $20^{\text {th }} 1975$ ), the second one being the establishment of Third Party Motor liability insurance as a mandatory insurance to all traffic (August $7^{\text {th }}$ 1975). Now, insurance sector is under supervision of the National Bank of Rwanda as regulator of financial sector. Many regulations and directives are in place for the stability of the sector and for customer protection.

\subsection{Claims Settlement Procedure}

Krishnan (2010) points out what the underlying claims management procedure involved. The first stage starts with the verification of occurrence of loss. The second stage is the verification of proof of loss to make sure that the loss occurred accidentally and it was insured. The third process is the negotiation stage to find out. The funding viewpoints, the volume and allocation of claims are assessed. Whereas, the operational deals with the operating features of a Claims settlement Procedure, like processing capacity, claims quantity and outstanding claims register, are assessed. The helpfulness of this analysis for efficient and ef- 
fective organization and management of the claims handling function is obvious. Claims handling procedures is a tool that allows analysis and predictions of the handling procedures.

\subsection{Financial Performance Indicators}

Financial ratios have been agreed and used as measures of financial performance of a company (Al-Shami, 2008; Malik, 2011). These ratios include Return on Assets (ROA), Return on Equity (ROE) and Return on Invested Capital (ROIC). $\mathrm{ROA}$ is a key indicator since it measures profitability on the total assets, which shows how well a company uses its asset to make earnings (Malik, 2011). Profitability in the insurance sector of Nigeria has been seriously affected by rising claim expenses (Vanguard, 2017).

According to Thachappily (2009) discussed about the profitability ratios as measures the margins and the returns such as; gross or net profit, ROA, ROE, ROCE. He also acertains that the return on resources used is divided into three types namely: ROA, ROCE.

Financial ratios should be computed regularly to indicate where the company has weakness or strength. Therefore ratio analysis is a tool to extend company's performance in place of profitabilities and liquidities.

\subsection{Claims Settlement and Financial Performance in Insurance Companies}

According to Ngui (2010) financial performance of a company is one of the ways which can be used to assess and check how well the company is utilizing its resources to generate income. Good examples to be used when measuring financial performance include operating income, earnings before tax, as well as net asset value.

\subsection{Empirical Literature}

According to reports from the Faculty of Claims of the Chartered Insurance Institute, it refers to the fact that in Europe, in recent years, there have been many changes in the way claims are handled, seen and managed. These changes are incremental and cumulative, rather than sudden and dramatic and this has created an environment of constantly changing and evolving claims. It is agreed that claims are much closer to the heart of the industry than ever before. It is believed that many cases are the biggest trigger for the profits and losses of an organization.

Francis and Butler (2010), in their study recommended that insurance company should strive to keep up a healthy relationship with its clients to improve its overall performance by reducing risks. One of the basic areas to observe and to promote such a healthy relationship is to make sure that insurance companies can prudently observe the main five key areas of claims management. This include proper control over claim management process, ensuring that they properly understand the need of their clients in order to ensure that they advise them on the right policy cover of model for their business, develop mutually relation- 
ship with other service providers in similar field of operation and also ensure that they get an information required for their advantage. For this study the researcher addresses the arrangement made to ensure that SONARWA General Insurance maintains good control of the claims process.

A study done by Scott (2015) emphasized that while the financial performance of company using ratios, some of the key indicators to prefer in return of Assets was that anything low $5 \%$ is not safe. Where return on equity and return on investment, anything within $10 \%$ and $14 \%$ are considered desirable. The term investment may refer to total assets or net assets. The funds employed in net assets in are known as capital employed. Net assets equal net fixed assets plus current assets minus current liabilities excluding bank loan.

\subsection{Critical Review and Research Gap Identification}

According to various written regarding to claims management and finance performance, researcher found that there are a few literatures discussing on claims management undertaken on insurance companies. Practically, they display percentage of the perception of clients complaining and some factors contributing to claims management and finance performance.

Some studies have highlighted that proper plans and control of claims process are necessary to ensure that complaints are registered, monitored and handled for needs that can ensure their future utility. However, little has been talked about the financial implications of these processes; planning, control, Monitoring and evaluation of claims. Moreover, no related research has been yet done to the developing Rwandan insurance sector constituting then a gap of knowledge in this market. The research is willing to add knowledge contributing to the development of the sector.

\subsection{Conceptual Framework}

Figure 1 illustrates the conceptual framework of the research through the Independent Variable:Claims management

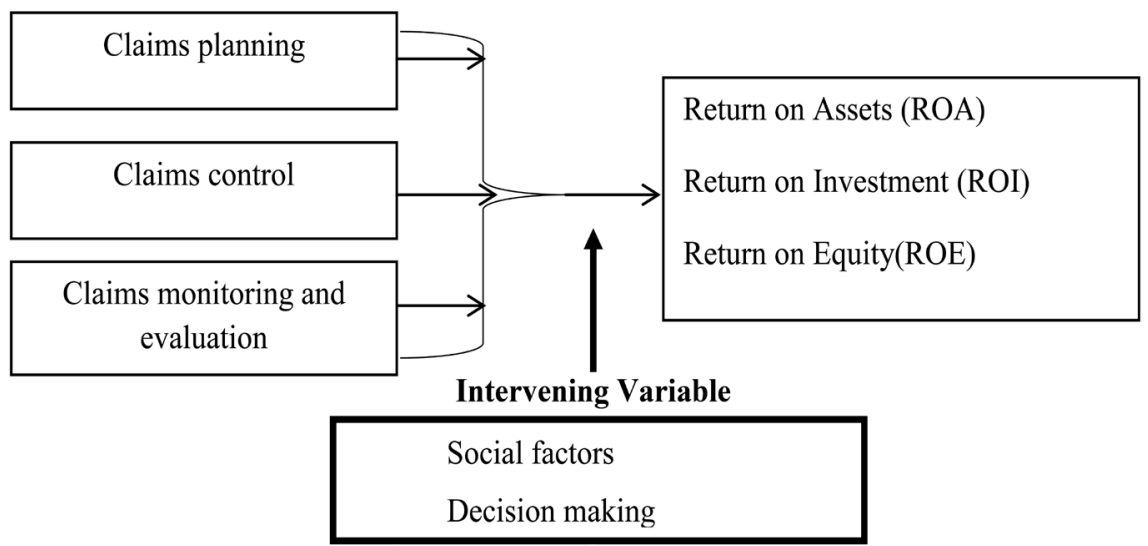

Source: Researcher (2020).

Figure 1. Conceptual framework. 
independent variable of claims management and the dependent variable being the financial performance of insurance companies. Claims management processes like planning, control, monitoring and evaluation are conceived to be the predictors of profitability of the company through its main financial performance indicators ROI, ROA, ROE. Social factors, decision making are considered as intervening variable to claims management processes where the attitudes of employees and the clients are paramount for the efficiency of this main business of insurance hence affecting the financial performance of this sector.

\section{Research Methodology}

This design is the roadmap which the researcher used in order to obtain the data to answer the objectives of the research. This captures reliable, unbiased and extremely generalizable results (Dannels, 2018). This study used a case study research design with descriptive and correlation design methods to present quantitative and qualitative data to be analyzed and interpreted according to the findings using SPSS Qualitative information collected through interview through gathering strong feeling of respondents on each item. This design was considered suitable because it is based in general description of the situation without manipulating the state of the subject. Quantitative data focus more on the number of respondents with majority having similar opinion about the same phenomenon concerning claim management and financial performance of the insurance company (Bakker, 2018). Financial aspects like investment income, comprehensive income, total assets and Total Equity for each financial year have been gathered in a table to compute the profitability ratios (ROI, ROA, ROE). A brief comparative analysis has been done between the rates found with the ones of the two African older insurance groups Jubilee group and Sanlam Group. The same comparison was also done to Rwanda insurance sector as stated in BNR report 2018.

\subsection{Target Population}

The researcher targeted all staff members of SONARWA General insurance company in Kigali city of Rwanda and average annual clients reporting for claims compensation. The study was conducted in all the main office branches of the company within Kigali city. The researcher targeted 93 permanent employees, 10 registered agents, 13 contracted brokers (SONARWA General Annual Report, 2018), and 205 claimants in Kigali (Sonarwa GI claims department 2018 report) of SONARWA General Insurance Company.

\subsection{Sampling Design}

The study calculated the sample size by using the formula of Slovin. The researcher used a confidence level of $90 \%$ and a margin of error of $10 \%$ while calculating the sample size as indicated below: 
where:

$$
n=\frac{N}{1+N(e)^{2}}
$$

whereby: $N$ represents the total target population of 321 people (employees, licensed brokers and agents and 2018 claimants from Kigali of SONARWA General Insurance).

$n$ represents the sample size to be calculated.

$e$ represents the margin of error (10\%). Despite the 5\% margin of error customarily used in empirical research, preliminary evaluation done during the pilot study indicated that the required information for the study could be obtained from a much smaller sample particularly of employees who possessed and exhibited high skills and competence on insurance matters. Additional sample from non-employees was deemed peripheral and back-up.

\subsection{Sample Size}

Table 1 shows sampling frame of participants classified into main categories, employees, agents and Broker, clients.

\subsection{Sampling Techniques}

The study used mixed method techniques which combined both probability and non-probability techniques. Probability sampling techniques included stratified method which was used to group the employees into departments. This kind of stratified method was used to identify relevant employees in each department to be sampled. In probability sampling, the researcher applied random sampling method to collect the data from the respondents in each identified stratum/department. Additionally, agents and brokers were identified using probability. The researcher obtained a list of all the 10 and 13 licensed agents of SONARWA G.I. and brokers respectively from BNR website which has a database of all licensed agents and brokers in insurance sector in Rwanda and contact them randomly to respond to the questionnaire. The clients were mapped in order to identify the ones residing in Kigali city. After identifying them, the researcher randomly contacted using telephone and requested them to participate to the survey. Non-probability sampling was used to collect the data from the top

Table 1. Sampling frame.

\begin{tabular}{ccc}
\hline Target population & Sample determination & Sample size \\
\hline Employees, Agents and Broker & 116 & $n=\frac{116}{1+116(0.1)^{2}}=54$ \\
Clients & 205 & $n=\frac{205}{1+205(0.1)^{2}}=67$ \\
Total & 321 & 121 \\
\hline
\end{tabular}

Source: Sonarwa G. I. Report (2020). 
level leaders of the company because they are considered to have the vital information needed for this study. Among the permanent staff, the researcher met three key managers of marketing, claims and finance departments for a short interview. They are day to day involved in claims management and financial activities as core operation. The researcher used purposive sampling to collect the information from the senior managers of each department.

\subsection{Data Collection Methods}

The researcher commenced the data collection method after successfully defending the proposal at Mount Kenya University. Upon the acceptance of the proposal at the institution, the researcher was issued with the letter of introduction which stipulates the purpose of undertaking this exercise. The researcher then formulated a letter seeking for an appointment from the senior management team of Sonarwa General Insurance company to book an appointment for collecting the data in their institution. A copy of introductory letter was attached to this appointment letter. After getting the acceptance, the researcher personally delivered the questionnaires to the respondents and waited for the respondents to fill the questionnaires. Semi structured interview was done to those who sought to have a quick session with the researcher. The researcher also collected on flash disk the soft copies of the financials of the company for the years 2014-2018.

\subsection{Data Collection Instrument}

The researcher used the questionnaires and structured interviews which were used to collect the data from employees, brokers, agents, key department managers and clients of Sonarwa General Insurance company. The questionnaire were formulated in a manner that it was easy to be understood and takes less time to be responded to. The questionnaire was prepared in English and included Likert scale design, dichotomous, closed ended (yes/no) as well as open ended questions. Afterwards the data collected and analyzed was sorted out in order to check the responses and verify whether all the questions are well addressed. Also, secondary data was collected and used to assess the financial performance of the company whereby the researcher computed financial ratios obtained from Sonarwa General Insurance financial records from 2014 to 2018.

\subsection{Reliability and Validity}

The content and validity of the questionnaire were ensured since the content covered the range of the general items being evaluated in the research. In this research case, all the main items in the questionnaire determined the actual dimensions internal claims management and finance performance in Sonarwa General insurance company. The construct validity was guaranteed by ensuring that the questionnaire conformed to the general theoretical predictions guiding 
the study. Validity was also achieved through vetting by supervisors and peers.

A reliability test was carried out to test the consistency of instruments being used in the project. A pilot study was conducted to establish procedures, materials, and parameters to be used in the main study. The internal reliability of the questionnaire was measured and calculated using the reliability analysis in SPSS Statistics. Table 2 documented the Cronbach's alpha value which was 0.701 and within the acceptable levels of internal consistency.

Table 2 indicates reliability statistics, where researcher has used SPSS Version 22.0 for measuring the reliablility. While researcher analyzed menu and selected the scale table of reliability analysis. In graph window which appearing the after, both the coded questionnaires in information set were selected and transferred to the variable side for testing by using Cronbach's Alpha test. A coefficient (alpha) of 0.701 was considered acceptable reliability of questionnaires.

\subsection{Data Analysis Procedures}

The information was collected, stored and coded in SPSS version 22.0. Data analysis was done using descriptive statistics. In this case, frequency tables and percentages were used. For descriptive statistics simple summaries were generated using SPSS from the observations made. Such summaries were quantitative, i.e. precipitating statistics and visuals, easy to understand graphs.

The variables were set in a 5-point Likert scale to allow the respondents to rate their choices in accordance to their degree of surety. The ratings were as indicated in the table below.

Table 3 indicates weighted means and introducing, where these ranges were used by the researcher to make inferences on statistics as to whether the respondents agreed with the statement presented in the questionnaire. Pearson Correlations were also used to ascertain the relationship between claims management and financial performance of the insurance company.

\subsection{Ethical Considerations}

The researcher ensured that the work is ethically carried out within the best

Table 2. Reliability statistics.

\begin{tabular}{cc}
\hline Cronbach's Alpha $^{\mathrm{a}}$ & N of Items \\
\hline 0.701 & 44 \\
\hline
\end{tabular}

Source: Primary Data (2020).

Table 3. Weighted means and introduce tables.

\begin{tabular}{ccc}
\hline Frequently applied & Very Strong & $1.00 \leq$ mean score $\leq 1.50$ \\
Occasionally applied & Strong & $1.51 \leq$ mean score $\leq 2.50$ \\
Hardly applied & Average & $2.51 \leq$ mean score $\leq 3.50$ \\
Never applied & Weak & $3.51 \leq$ mean score $\leq 4.50$ \\
I don't know & Very Weak & $4.51 \leq$ mean score $\leq 5.00$
\end{tabular}


practices of conducting a research. This is to mean that the researcher must assure the respondents that the study was carried out with anonymity of the respondents. This process was voluntary and in case a respondent is not willing to participate, the researcher did not force them to do so.

\section{Analysis}

\subsection{General Information of the Respondents}

Demographic information provides insight understanding about the characteristics of the respondents who were sampled during the study. This was considered to be necessary because it assists the researcher to understand the targeted group in details.

Table 4 indicates that majority of the employees represented by $57.4 \%$ were female and $42.6 \%$ were male. Women make up a slightly large percentage of the entire workforce, but even this figure includes many who work behind a desk, often in product design, management or secretarial roles. However, this implies that although there might be a slight disparity on the representation of the gender, insurance job does not attract any specific type of gender. Qualification for getting a job depends on merits but not the type of gender. On the side of the clients, $70 \%$ were male while $30 \%$ were female.

Table 5 presents the findings about the length of time which respondents have worked or been clients in Sonarwa General Insurance. It was revealed that $42.6 \%$ of the respondents who formed the majority have worked in the company for about 3 to 6 years, $29.3 \%$ said that they have served for about 7 to 10 years,

Table 4. Gender of the respondents.

\begin{tabular}{ccccc}
\hline Variables & \multicolumn{2}{c}{ Employees, brokers and agents } & \multicolumn{2}{c}{ Clients } \\
\hline Gender & Frequency & Percent & Frequency & Percent \\
Male & 23 & 42.6 & 28 & 70.0 \\
Female & 31 & 57.4 & 12 & 30.0 \\
Total & 54 & 100.0 & 40 & 100.0
\end{tabular}

Source: Primary Data (2020).

Table 5. Number of years in Sonarwa General Insurance.

\begin{tabular}{ccccc}
\hline \multirow{2}{*}{ Work length } & \multicolumn{2}{c}{ Employees, brokers and agents } & \multicolumn{2}{c}{ Clients } \\
\cline { 2 - 5 } & Frequency & Percent & Frequency & Percent \\
\hline $1-3$ years & 8 & 14.8 & 7 & 17.5 \\
$3-6$ years & 23 & 42.6 & 7 & 17.5 \\
7 - 10 years & 16 & 29.6 & 14 & 35.0 \\
More than 10 years & 7 & 13.0 & 12 & 30.0 \\
Total & 54 & 100.0 & 40 & 100.0 \\
\hline
\end{tabular}

Source: Primary Data (2020). 
$14.8 \%$ of the rest stated that they worked for about $1-3$ years. On the side of the clients $35.0 \%$ said that they have been clients of the company for about 7 to 10 years, $30 \%$ stated that they have been clients for a period more than 10 years $17.5 \%$ stated that they have been clients for about 1 - 3 years and 3 - 6 years respectivesly.

This implies that majority of the employees in Sonarwa have wealth of experience having served in the company for quite a number of years. It also implies that employee turnover in the company is low and therefore majority of those employed maintain their jobs for a long period of time. This is a good sign of stability of the company especially when it comes to implementation of long term goals where most of the employees understand the vision of the company and takes constant steps of implementing it. Similarly, most of the clients of Sonarwa GI have been loyal to the company for more than seven years. This translates the fact that insurance is more than building customer relationship. As much as more staff are loyal also more customers that they served tend to be loyal to the company.

The study sought to assess the education qualifications of the respondents in in Sonarwa General Insurance by asking them to state their highest level of education as indicated in Table 6 . It was observed that $66.7 \%$ of the employees sampled who were the majority had bachelor degree in various discipline areas and $33.3 \%$ had master degree. This implies that in average, majority of the respondents working in Sonarwa are well educated and therefore have the necessary technical skills that are required to execute insurance tasks especially claims management which is the subject case of this study.

\subsection{Presentation of Findings}

\subsubsection{Claims Management Processes in SONARWA General Insurance}

The first objective was to assess the claims management processes of the company trough predictors like claims planning, claims control, claims monitoring and evaluation.

\section{Claims Planning in SONARWA General Insurance}

The researcher sought to assess claims planning processes in SONARWA General Insurance in order to establish its relationship with financial performance. First, respondents were asked to indicate whether they undertake current processes of claims planning processes. Some of these procedures suggested are common processes used in claims management and therefore respondents were

Table 6. Respondents high level of education.

\begin{tabular}{ccc}
\hline Education level & Frequency & Percent \\
\hline University degree & 36 & 66.7 \\
Master degree & 18 & 33.3 \\
Total & 54 & 100.0 \\
\hline
\end{tabular}

Source: Primary Data (2020). 
asked to rate if they are frequently applied; occasionally applied, hardly applied, never applied of perhaps some do not know.

The study reveals that majority of the respondents agreed that claims notification process is frequently applied in the process of claims management as indicated with a mean $1.00 \leq 1.3704 \leq 1.50$ and a heterogeneous standard deviation of 0.87516 as indicated by Table 7 . There must be a formal notification of any event that is likely to give a rise to a claim under the policy, promptly or immediately. This could be done in writing, verbally or via phone, and must conform to the requirement in this regard as stated in the policy.

The second step is Verification of records which according to majority of the respondents indicated by a mean rating of $1.00 \leq 1.2407 \leq 1.50$ and a heterogeneous standard deviation of 0.69866 stated that it is frequently conducted. The third process is claims reserving which is also frequently applied as indicated by the majority of the respondents shown by a mean ration of $1.00 \leq 1.2222 \leq 1.50$ and a heterogeneous standard deviation of 0.81650 . The fourth process which is also frequently applied is the negotiation of payment a mean ration of $1.00 \leq$ $1.2963 \leq 1.50$ and a heterogeneous standard deviation of 0.94429 meaning that majority of the respondents agreed that indeed they usually undertake this process.

\section{Claims settlement}

The study sought to assess the process of claims settlement in insurance company and therefore assess various aspects involved in payment of claims. Respondents were to rate the applicability of suggested variables whereby they had to respond either by strongly agreeing, agree, undecided, disagree or strongly disagree. The variables were set in a Likert scale to allow the respondents to rate their choices in accordance to their degree of surety.

On the issue whether claims are paid on a first come first pay basis majority of the respondents disagreed as indicated by a mean with a mean $3.51 \leq 3.5000 \leq$ 4.50 and a heterogeneous standard deviation of 1.07721 as shown by Table 8 . This implies that claims are not queued in the order of occurrence, or even order of documentation. Recent claims are sometimes paid before older ones due to certain factors like early full documentation of the claims or based on some commercial relationship as stated by key informants during the interview. This practice may create unfair treatment of clients. When this occurs, claims personnel

Table 7. Descriptive Statistics showing claims planning $(\mathrm{N}=54)$.

\begin{tabular}{ccc}
\hline Variables & Mean & Std. Deviation \\
\hline Claims notification process & 1.3704 & 0.87516 \\
Verification of records & 1.2407 & 0.69866 \\
Claims reserving & 1.2222 & 0.81650 \\
Negotiation of payment & 1.2963 & 0.94429 \\
Payment of Claims & 1.3704 & 0.87516 \\
\hline
\end{tabular}

Source: Primary Data (2020). 
Table 8. Claims payment process in Sonarwa General Insurance $(\mathrm{N}=54)$.

\begin{tabular}{ccc}
\hline Variables & Mean & Std. Deviation \\
\hline Claims are paid on a first come first pay basis & 3.5000 & 1.07721 \\
A pre-set budget of expenditure on claims is followed & 1.3519 & 0.61911 \\
Claims Department is in charge of the payment process & 1.5000 & 0.77093 \\
Payments are made as per set company benchmarks & 1.5185 & 0.92636
\end{tabular}

Source: Primary Data (2020).

are not sure which claims to give priority. The ideal situation is where all claims are paid expeditiously within set benchmarks, with very few variations.

This is similar to the study done by Angima and Mwangi (2017) which reveals that majority of the respondents also strongly agreed that a pre-set budget of expenditure on claims is followed as indicated by a mean rating ranging between $1.00 \leq 1.3519 \leq 1.50$ and a heterogeneous standard deviation of 0.61911 . Where claims managers are allocated a fixed budget for payment of claims irrespective of actual amount of claims ready for payment, it becomes a challenge when the issue of liquity intevenes. Meanwhile claims department normally works out a budget of claims implemented since the beginning of the year. This is because clients who have suffered a loss expect to be paid promptly. Failure to pay claims when they fall due is a major contributor to negative publicity against insurance companies. One of the manager states that the projected budget of claims sometimes is exceeded due to huge claims unexpected or catastrophy. This leads to growth of outstanding claims as the preset budget of claims to be settled is initially approved before the occurrence of claims.

The interviewed participants on how claims management systems/process was conducted in SONARWA General Insurance Company and they said that the main steps are as follows:

- Reception and registration of a claim declaration, inventory of repairs to make and all required supporting documents.

- Loss assessment by Sonarwa Experts and review of the list of damages on the property.

- Computation and creation of reserves of amount of compensation.

- Negotiation with the claimants on the amount of compensation and adjustment of reserves.

While seeking to assess some of the factors considered in claims control which may affect the financial performance of the insurance company, majority of the respondents stated that one of the important controls necessary to be considered in the company is the claims cost control as indicated by a mean of 1.1852 in Table 9. Cost control is important because it sets precedence on the amount of contribution which a client will be charged for a cover on renewal of his policy and help to know the accurate compensation for genuine claims as highlighted by the claims manager in the interview.

Claims Monitoring and evaluation 
The above Table 10 revealed that claims monitoring process is part of claims management procedures used in Sonarwa General Insurance. The study established that majority of the respondents stated that claims ratio is moderately used as indicated by a mean of 1.6852. The Claims Ratio can be used as a tool for monitoring and evaluation to measure the number of claims in a period and divides that by the earned premium for the same period. It's important to note that insurance is the business of managing risks and, to do that well, the insurer needs a thorough understanding of the incurred claims ratio.

The claims management in SONARWA General Insurance

The researcher wanted to know aspects of claims management recognized as efficient characteristics of claims process. Aspects like speed, customer satisfaction, professionalism and cost of claims have been proposed to the respondents to rank them for this purpose. The variables were set in a Likert scale to allow the respondents to rate their choices either by strongly agreeing, agree, undecided, disagree or strongly disagree.

Table 11 shows the aspects used to measure the efficiency of claims management in a general insurance company. This question was administered to the clients of SONARWA General Insurance in order to capture their views on these matters. The speed in settling claims was rated average mentioned by the

Table 9. Claims control $(\mathrm{N}=54)$.

\begin{tabular}{ccc}
\hline Variables & Mean & Std. Deviation \\
\hline Claims cost control & 1.1852 & 0.39210 \\
Claims litigation management & 1.2593 & 0.44234 \\
Claims processing procedures & 1.1111 & 0.37197 \\
\hline
\end{tabular}

Source: Primary data (2020).

Table 10. Claims Monitoring and evaluation.

\begin{tabular}{ccc}
\hline Variables & Mean & Std. Deviation \\
\hline Claim ratio & 1.6852 & 0.82013 \\
Claims settlement time & 1.4074 & 0.56697 \\
Outstanding claims & 1.6852 & 0.82013 \\
Number of claims settled outside the court & 1.6296 & 0.68118 \\
\hline
\end{tabular}

Source: Primary Data (2020).

Table 11. Claims management efficiency in Sonarwa General Insurance Company.

\begin{tabular}{ccc}
\hline Variables & Mean & Std. Deviation \\
\hline Speed & 3.35 & 1.189 \\
Customer satisfaction & 3.30 & 1.244 \\
Professionalism & 2.73 & 1.261 \\
Cost & 2.22 & 0.832 \\
\hline
\end{tabular}

Source: Primary Data (2020). 
respondents as per the mean rating between $2.51 \leq 3.35 \leq 3.50$. Claimants really appreciated and valued the company by looking at the turnaround time of claims process up to the actual settlement. In SONARWA General, respondents revealed that the company has really improved on this but there are still areas to improve to reach the best practices.

By comparison, the study showed that the claims management processes in SONARWA General Insurance are quite the same as the ones of other reputable insurance companies. However, the company is still relying on manual process starting from the reception of the declaration form until settlement and all paper sheets gathered in a physical file. This can slow the process with a lot of workflow whereas the world is now using technology to minimize/detect fraud, minimize the turnaround times and improve communication with clients. Comparing with the claims management processes at Jubilee Insurance Company, they are automated claims processing, fraud-free claims settlement and built-in customer self service (Jubilee Report, 2018).

\subsubsection{Financial Ratios and Performance in SONARWA General Insurance Company}

The second objective was to assess the level of financial performance indicators of the company. The researcher consulted the financial statements of the company for the financial year 2014 to 2018 and computed the profitability ratios ROI, ROA and ROE and inquired on reasons of fluctuation or stagantion.

According to the annual financial statements of Sonarwa General Insurance Company 2014-2018, the financial ratios indicates that there has been a constant stagnation of ROI as indicated by $3.6 \%$ of growth in 2014 and the same percentage was observed in 2018 (see Figure 2). The changes over the four years were not sound compared to other ratios. Although there have been slight changes, the graph indicates that these have been a slight changes. Moreover, the same graph shows that the ROA had slight changes in range of $10 \%$ leading to get it quite stable. On the contrary, ROE has significant fluctuations over the entire period of review with a very sharp increase in 2016 (250\%) followed by a sharp decrease in 2017 (26.9\%) due to a revaluation of assets.

The respondents were asked to rate the extent which claims management can

\begin{tabular}{|c|c|c|c|c|c|c|}
\hline \multirow{4}{*}{ 离 } & \multirow{4}{*}{$\begin{array}{r}300 \\
250 \\
200 \\
150 \\
100 \\
50 \\
0 \\
-50 \\
-100\end{array}$} & \multirow{3}{*}{\multicolumn{5}{|c|}{ (n) }} \\
\hline & & & & & & \\
\hline & & & & & & \\
\hline & & 2014 & 2015 & 2016 & 2017 & $201 \varepsilon$ \\
\hline & $\because-R O I$ & 3.6 & 3 & 2.2 & 3.1 & 3.6 \\
\hline & $=R O A$ & 0.7 & -13.9 & 19.9 & 10 & -1.8 \\
\hline & $-\mathrm{ROE}$ & 1.5 & -50.7 & 250.2 & 26.9 & -4.7 \\
\hline
\end{tabular}

Source: Secondary Data (2020).

Figure 2. SONARWA G.I. Financial performance measured by financial ratios (\%). 
affect the ROI and it was observed that $68.5 \%$ stated that it affects the profitability of the company to a very high extent even though for Table 12 , the insurance company has not been performing relatively well over the period 2014-2018. This can be as a result of various factors which among them include the claims management process.

To understand more about this, an interview was carried out with managers of concerned department about the ways claims management in Sonarwa General Insurance affects the ROI financial performance indicators. Two respondents said that: "Claims management affects ROI because if claims costs or compensations are not well done, they will be much cash flow, many payments then the company does not get funds to invest. Therefore, Lower ROI as the company has invested small amount. Again, due to issue of liquidity, the company may need to divest/break the deposits/investments earlier made before they generate projected ROI. There is a need to manage carefully the claims, well compute the amount of compensation to be able to get enough amount of investment and stable funds investible".

A comparison of profitability rates has been done between SONARWA GI with other reputable older African insurance groups Jubilee (83 years) and Sanlam Group (100 years) using their Integrated annual report and Financial statements 2018. The ROI of Jubilee Holdings was $7.2 \%$ and $7.6 \%$ in 2017 and 2018 respectively (Jubilee Holdings Integrated Report \& Financial Statements 2018 annual report). This rate is higher than the one of SONARWA GI and its trend shows a slight increase towards stagnation like the one of SONARWA GI.

Similarly, Sanlam Group has registered almost the same ROI of 7.7\% and 7.5\% for the same period showing a slight decrease towards stagnation like the one of SONARWA GI (Sanlam Annual report and Financial Statements, 2018).

Table 13 indicates on Return on assets where a majority of the respondents

Table 12. Return on investment.

\begin{tabular}{ccc}
\hline Response & Frequency & Percent \\
\hline Very high & 37 & 68.5 \\
Moderately high & 13 & 24.1 \\
I don't know & 3 & 5.6 \\
Low & 1 & 1.9 \\
Total & 54 & 100.0 \\
\hline
\end{tabular}

Source: Primary Data (2020).

Table 13. Return on assets.

\begin{tabular}{ccc}
\hline Response & Frequency & Percent \\
\hline Very high & 37 & 68.5 \\
Moderately high & 17 & 31.5 \\
Total & 54 & 100.0 \\
\hline
\end{tabular}

Source: Primary Data (2020). 
consisting of $68.5 \%$ stated that claims management very highly affects the return on assets. Figure 2 shows that in 2014, the return in assets stood at $0.7 \%$ then it is followed by a sharp decline to $-13.9 \%$ in 2015 . In 2016 , the company undertook the revaluation of the assets and the value of the property by then went up with a sharp rate of $19.9 \%$ In 2017, the company conducted a re-evaluation of the assets and its value had significantly declined following subsequent two years and ended up to $-1.8 \%$ in 2018 .

The researcher has gone further to understand better the figures above, then an short interview with the key informants mainly managers of the concerned departments finance, general accounting and claims management about the ways claims management in Sonarwa General Insurance affects the ROA financial performance indicators, With referencing to response offered by respondent commented that: "As much as the ROA involve the return got vis a vis the total assets of the company, claims management engage much cashflow in the company and affect the total assets of the company. For sonarwa General, the total assets comprised also with property and revaluation gains which affected this ratio. Claims management would be seen in way it may reduce the total assets like funds invested or urge the company to sell off some fixed assets for example to get liquidity and pay out liabilities including claims. Therefore, Sonarwa has tried as much as possible to manage well claims so as to protect its acquired assets".

Comparison done to Jubilee Holdings, this company has registered $4.3 \%$ and $3.2 \%$ respectively in 2017 and 2018 and it was 5.3\% in 2014. This shows a slight decreasing trend over the years since 2014 quite same trend like SONARWA GI for the same period.

Similarly, Sanlam Group has registered a ROA of $0.2 \%$ and $-6.8 \%$ for the same period showing a decrease and a negative ROA in 2018 like SONARWA GI for the same year (Sanlam Group, 2018).

In general, the three companies have been experiencing a decrease of ROA over the two financial year 2017-2018 with a negative ROA in 2018 for SONARWA GI and Sanlam Group. We need to note that ROA of Rwanda insurance industry is ranging between $-7 \%$ to $3 \%$ during the period under review but was still under the minimum required (4\%) by the regulator.

Table 14 indicates impact on Return on equity over the last five years. Majority of the respondents stated that claims management has affected the ROE of

Table 14. Return on equity.

\begin{tabular}{ccc}
\hline Response & Frequency & Percent \\
\hline Very high & 32 & 59.3 \\
Moderately high & 13 & 24.1 \\
I don't know & 9 & 16.7 \\
Total & 54 & 100.0
\end{tabular}

Source: Primary Data (2020). 
the company very highly as indicated by $59.3 \%$ of the sampled respondents. Figure 2 also indicates a sharp increase from 2015 from $-50 \%$ to $250 \%$ rise followed by a sharp decline in 2017 to about $26.7 \%$. The sharp increase might have been due to revaluation of the property as above explained. The equity reduced in 2016 but get risen again in 2017 after a reclassification of the previous fair value of the property available for sale to the business by the shareholders of the company.

In the interview with the managers about the ways claims management in Sonarwa General Insurance affects the ROE, with referencing to response offered by respondent said that:

In any business, the shareholders needs the business to grow and get return on the capital invested. Management of claims in sonarwa has been done such way the company gets sound underwriting results instead of touching on capital invested. Claims cost are deducted from total earned premium/revenue to arrive at underwriting results. However, this result has been not satisfactory in many financial years not only for sonarwa but also in the whole industry.

Comparing this ROE rates to the ones of Jubilee Group, the latter registered $5.6 \%$ and $4.2 \%$ whereas for Sanlam Group, it is $1.3 \%$ and $-124 \%$ respectively in 2017-2018. This shows also a slight decrease as well. For the Rwandan insurance sector, ROE fluctuated between $-24 \%$ and $10 \%$ for the same period.

\subsubsection{Correlation between Claims Management Processes and Financial Performance Indicators}

For the third objective of the study, the researcher also sought to find out the link between claims management and financial performance of an insurance company by linking the two variables using Pearson correlation. Table 15 below presents the results of the study.

The study indicates that claims planning and claims $M \& E$ has a positive correlation with ROA which is indicated by a Pearson Correlation value of $(0.141$ and a $\rho$-value of $0.309 ; 0.145$ and a $\rho$-value of 0.296 ) respectively as presented in Table 15. This implies that although there is a positive correlation between claims planning and claims $\mathrm{M} \& \mathrm{E}$ on ROA, the correlations itself are not statistically

Table 15. Correlation between claims management processes and financial performance indicators.

\begin{tabular}{ccccc}
\hline Variables & Pearson Correlation & ROA & ROI & ROE \\
\hline \multirow{2}{*}{ Claims planning } & Pearson Correlation & 0.141 & $0.481^{\star *}$ & 0.043 \\
Sig. (2-tailed) & 0.309 & 0.000 & 0.757 \\
Claims control & Pearson Correlation & -0.118 & -0.005 & 0.079 \\
Claims monitoring and & Sig. (2-tailed) & 0.396 & 0.970 & 0.570 \\
evaluation & Pearson Correlation & 0.145 & $0.329^{*}$ & $0.276^{*}$ \\
\hline
\end{tabular}

${ }^{\star}$ Correlation is significant at the 0.05 level (2-tailed). Source: Primary Data (2020). 
significant. Therefore an insurance company cannot specifically rely on planning and $\mathrm{M} \& \mathrm{E}$ alone to improve financial performance of the company. Other factors have to come into play for the realization of a sensible financial performance.

It was also observed that claims control has a negative correlation with ROA which is indicated by a Pearson correlation value of $(-0.118$ and a $\rho$-value of 0.396). However, the correlation is not statistically significant. It was observed that claims planning and claims $\mathrm{M} \& \mathrm{E}$ has a significant positive correlation with ROI indicated by a Pearson Correlation value of $\left(0.481^{* *}\right.$ and $\rho$-value of 0.000 ; $0.329^{*}$ and a $\rho$-value of 0.015: $\left.\rho \leq 0.05\right)$. The negative correlation value of ROA implies that for every unit decrease in claims control, there is a corresponding increase in profitability, as measured by ROA, while keeping other variables constant. However, the correlation is not statistically significant.

\section{Conclusion}

In conclusion, the study reveals that in general in as much as Sonarwa General Insurance Company has tried to improve the process of claims management in the recent past, they are still having some challenges like late notification which is occasionally witnessed during claims management process. Most policies state that the insured should notify their insurer of a claim promptly. However, there are some incidences where some clients present their notification at a later date when the loss occurs. It is the insured's responsibility to prove that they have suffered a loss, and the loss was caused by a peril which is covered by the policy.

Therefore, the researcher suggests the insurance company to invest more in claims process-based technology to improve customer service. Automated processes with a client portal would speed up the claims settlement, accurate information, records keeping, and improve communication between the parties.

Proper claims planning, controls and monitoring need to be put in place which promptly handle claims management in order to avoid having a lot of outstanding claims.

This will enable them to control some of the incidences which may cause the company go at a loss in the long run.

The company also has to improve on their monitoring and evaluation of risks by investing more in technology which will improve the process of investigating and reporting the risk in real time and therefore reduces the challenge of poor investigation.

These processes well done will improve the claims management and affect the financial performance of the company as claims are main aspect hitting the profit and loss account of the company.

\section{Conflicts of Interest}

The authors declare no conflicts of interest regarding the publication of this paper. 


\section{References}

Al-Shami, A. (2008). Determinants of Insurance Companies Profitability in UAE. Unpublished Master's Thesis, Kedah: University of Utara.

Angima, C. B., \& Mwangi, M. (2017). Effects of Underwriting and Claims Management on Performance of Property and Casualty Insurance Companies in East Africa. European Scientific Journal, 13, 358. https://doi.org/10.19044/esj.2017.v13n13p358

Ashturkar, P. B. (2014). Comparative Study of Effectiveness of Claims Settlement Operations in Indian Life Insurance Companies. International Journal of Advance Research in Computer Science and Management Studies, 2, 148-155.

Bakker (2018). Importance of Claims Management in the Insurance Sector. Unpublished Thesis.

BNR (2018). Annual Report. Claims Reports from the Faculty of Claims of the Chartered Insurance Institute (2007).

Dannels, S. A. (2018). Research Design. In The Reviewer's Guide to Quantitative Methods in the Social Sciences (pp. 402-416). Abingdon-on-Thames: Routledge. https://doi.org/10.4324/9781315755649-30

Francis, P., \& Butler, S. (2010). Cutting the Cost of Insurance Claims: Taking Control of the Process. Paris: Booz \& Company. http://www.booz.com

Gahigi (2017). Technology-Based Industrialization of Claims Management in Motor Insurance. In for mationssysteme in der Finanzwirtschaft.

Jubilee Report (2018). Integrated Report \& Financial Statements.

Krishnan, B. (2010). Claims Management and Claims Settlements in Life Insurance. The Journal of Insurance Institute of India, 36, 49-57.

Kusimo, T. (2016). World's Top 10 Insurance Companies.

Malik (2011). Cutting the Cost of Insurance Claims: Taking Control of the Process. Paris: Booz \& Company. http://www.booz.com

Ngui (2010). Foundations of Insurance Law, Agency and Salesmanship (p. 170). Lagos: Mbeyi and Associates (Nigeria) Ltd.

Sanlam Group (2018). Annual Report and Financial Statements.

Scott, W. R. (2015). Appraisal of the Stakeholder Management Model in the Insurance Industry. European Journal of Business and Management, 4, 49-45.

http://www.iiste.org

Thachappily (2009). Profitability Ratios as Measures the Margins and the Returns Such as: Gross or Net Profit. Lagos: International Journal Trend in Scientific Research and Research Development.

Vanguard (2017). GIS for the Insurance Claims Process: Five Steps for an Effective Workflow. Sacramento, CA: ESRI White Paper.

Wairimu, M. K. (2010). Challenges in Management of General Insurance Claims in Kenya. MBA Thesis, Nairobi: School of Business, University of Nairobi. 